\title{
1. Beyond the market failure argument: Public banks as stability anchors*
}

\author{
Ana Rosa Ribeiro de Mendonça and \\ Simone Deos
}

During the 1950s and 1960s, in a political and economic scenario still heavily influenced by the so-called 'Keynesian consensus', many economists advocated for direct state participation within banking systems, a view often shared by policymakers. In the following decades, there was a drastic change in the understanding of the state's proper position in the economy within the scope of the new neoliberal policies codified in the Washington Consensus, which led to a widespread process of privatization. This wave of privatization resulted from a growing perception on the part of governments that the state's role in financial institutions tended to hinder, rather than stimulate, financial development (Jeanneau, 2007). However, despite the widespread privatization process observed in the 1990s, bank assets controlled by states still proved significant (Yeyati et al., 2007).

For the period 1998-2004, there was a global trend, with the exception of some Asian economies, of reduction or, at least, stabilization in the ratio of state-owned bank assets over total bank assets. This downturn mirrored the great privatization wave of the 1980s and 1990s, in tune with the widespread perception that public financial institutions perform poorly, as demonstrated by their systematically lower indicators as compared to private banks (Novaes, 2007).

However, in 2008 and 2009, in the face of an intense crisis in the financial systems of most countries, the debate surrounding public banks was revived, and one can identify a shift in the view on the role they should play. On the one hand, the renationalization of major private financial institutions in countries with mature financial systems, such as the United States and the United Kingdom, was part of the agenda. On the other hand, the way in which public financial institutions intervened to confront and minimize detrimental consequences of crisis, as in Brazil, Germany

* The authors are grateful to Brunno Henrique Sibin for his help with this chapter. 
and China, drew attention to a new vector of action for these entities. Concurrently, the unquestionable leading role private institutions played in creating the extremely fragile financial environment that enabled the crisis stimulated the development of new proposals of action on the part of public institutions (Lapavitsas, 2009).

A large part of the literature surveyed understands that the role to be played by public institutions is coupled with the perception of a certain immaturity, or incompleteness, in the development of banking systems and markets. In this sense, public financial institutions are justified as a way of bridging gaps left behind by the private sector in their provision of credit, or lack thereof, to some economic segments and/or geographical areas, and even in the provision of some other types of financial services. We call this perspective of analysis the 'conventional view', and consider it quite narrow.

In contrast, we believe that these institutions can, and indeed must, play an important role even in economies with a highly developed private sector, that is, in economies with 'mature' financial systems. They prove crucial both in addressing segments not adequately serviced by the private sector - but remain relevant for the local, sector or national economies and to contributing to the implementation of financial policy. Besides this more 'isolated' action, which we believe is performed not only to minimize market failures and gaps, but also to create non-existent markets, public institutions should act in other spheres. These include: (1) competition regulation in markets and the creation of new markets; (2) anticyclical performance to both avoid the development of a highly fragile system (in the Minskyan sense), and to act during moments of great fragility in financial systems by establishing an informal safety net and/or guaranteeing the maintenance of credit operations.

The purpose of this chapter is to critically consider ideas that permeate the conceptual debate on the role of public financial institutions. Thus, the key questions underlying this discussion and guiding the literature review concern the need for these institutions in economies with different characteristics, central or peripheral economies, and concurrently relates to such institutions' embeddedness in the political economy and their performance profiles. A reflection on the role of these institutions has to take into account the historical moment, the institutional framework, or the economic and financial structure in which such institutions exist. Indeed, this role cannot be separated from the institutionality of each financial system, especially concerning their form, development and regulatory framework. Moreover, one must consider the origins, structure, governance, logic of action and regulation to which public financial institutions are subject. The disregard of these specificities impoverishes the 
theoretical exercise of reflection and even detaches it from reality, at least from context-specific realities. To this one must add the frequently explicit ideologization of arguments, which makes this discussion a far from trivial exercise.

The role actually played by public financial institutions, and that which they could play, stands as the leitmotif for the present analysis, and we try to conduct it based upon an understanding of uncertainty and instability as central concepts. Following this introduction, the first section discusses different views on the role of public banks, mainly within the credit market. The second section evaluates the broader role played by such institutions, based on a post-Keynesian approach. Last, final remarks are presented by way of conclusion, asserting the significance of the discussion surrounding resource allocation in credit markets and deducing the corresponding need for state presence, we defend the position that public banks should be used to reduce the inherently cyclical behaviour of markets.

\section{PUBLIC BANKS AND RESOURCE ALLOCATION IN CREDIT MARKETS}

Over the past several decades, there were moments when the question of public financial institutions was discussed in academic circles, among policymakers, and even by society in general. Throughout this debate, lines of argumentation were primarily built around the role these institutions play in the credit market and, more specifically, their mechanisms and decisions related to credit allocation. A closer examination of almost all such arguments reveals that this debate was largely predicated upon the concept of market imperfections, especially credit market imperfections, leading to an opposition between those who posit the relevance of 'market failures' and those who rather indicate that of 'government failures'. Advocates of public financial institutions understood their intervention as necessary in order to allocate credit to those economic sectors and/or segments that would otherwise remain unserved (Stiglitz, 1994), while critics of these institutions who founded their analyses upon the concept of government failures argued that public bank credit allocation would result in distortions and even higher costs for the economic system (Caprio et al., 2004; Hanson, 2004).

However, it is important to emphasize that the perception of gaps in the credit allocation process is also present among authors who do not build on the concept of perfect markets. When constructing arguments, they refer to the need for intervening in credit markets, especially in contexts where the private sector cannot guarantee adequate mechanisms to finance 
spending decisions, mainly on investments that prove crucial for generating income and employment in capitalist economies.

In order to better understand these various positions, this section is organized as follows. First, we will present different lines of argumentation based on the perception of 'market failures' and the presence of externalities, referring to a perspective in which the best allocation for scarce resources is central - we call it the conventional view. Next, we will discuss arguments that assert the necessary role of the state's presence within credit markets, building on the belief that it is important to guarantee financing for certain spending categories.

\section{Market Imperfections and State Intervention}

The conventional arguments highlighted above require further evaluation and will thus be discussed in greater depth next. First, however, it is worth underlining that the leitmotif of this discussion is not historical time, that is, the moment in time in which such arguments were brought forward, but, rather, the polarity between those who defend and those who attack the direct presence of the state - as owner - in the banking sector. Before entering into this discussion, we must make some remarks on the general rationale of state intervention in financial markets, derived from this conventional approach, which itself stems from neoclassical thought centred upon ideas of market perfection/imperfection and the generation of externalities.

Yeyati et al. (2007) attempt to parse the set of ideas underlying this rationale for state intervention in financial markets. The first group of ideas points to the need for intervention in order to guarantee the soundness and safety of the financial system, noting the inherent fragility of financial institutions, particularly of banks. The first vector of this fragility is evident within the problem of maturity transformation, as financial institutions raise funds in the short run and maintain illiquid and longterm assets. In addition to the issue of maturity transformation, these authors stress other characteristics inherent to banking institutions that generate negative externalities - such as bank runs and bankruptcy - and demand intervention. As institutions with high leverage ratios, banks tend to adopt less conservative behaviour than that expected by depositors, demanding intervention from outside the market. The logic underlying this set of ideas is founded upon the justification for prudential regulation, that is, for regulation that guarantees soundness of and trust in the banking system. We emphasize that the central point of this argumentation lies in the special characteristics of banking institutions that generate far-reaching negative externalities when such institutions operate jointly in the market, thus requiring state intervention. 
The second group of arguments stresses the need for intervention as a way of reducing market imperfections derived from costly and asymmetric information, especially in the banking business, which carries out information-intensive operations. This asymmetry is present both in the relationship between credit suppliers and demanders, which can lead to credit rationing, and in operations between depositors and depositcollecting institutions. In this context, asymmetric information creates imperfect markets, as the results obtained are suboptimal in terms of both price and quantity.

A third set of arguments for state intervention is based on the opportunity for financing socially relevant projects, with the belief that they produce positive externalities despite being less financially profitable. In this case, the market is not an appropriate mechanism for resource allocation because 'private lenders may have limited incentive to finance projects that produce externalities' (Yeyati et al., 2007, p. 220). Alongside this argument is the view that private banks may operate in ways that frustrate expansionary and/or anticyclical monetary policies, regarding either volumes negotiated or prices charged, since they fail to internalize the fact that they would help steer the economy out of an undesirable trajectory if they responded positively to such policies. In these cases, state intervention solves the coordination problem and makes the expansionary monetary policy more effective.

Finally, the fourth group of arguments for intervention is tied to the need to promote financial development and provide competitive banking services to agents who are seen as less attractive to private capital. The advocates of this form of intervention argue that guaranteeing access to banking services may lead to financial development with positive externalities, including growth and poverty reduction (Burgess and Pande, 2005). Another argument posits the presence of public banks as a means of guaranteeing competitive behaviour in otherwise collusive markets.

\section{Public Banks: The Conventional Controversy}

A question that arises from the arguments listed above - which, at different levels, justify the need for intervention - is related to the form the intervention assumes. The total or partial ownership of banking institutions is but one of many possible forms, together with prudential regulation, functional regulation and direct subsidies. However, a careful reading of the arguments above points out that, to a greater or lesser degree, the public ownership of institutions is an appropriate form of intervention. In other words, intervention through financial institution ownership is an effective way of minimizing credit market failures, while dealing with cases in which 
externalities, positive and negative, are highly significant. It is further justified by financial underdevelopment and the tendency towards collusion, factors that indicate less competitive markets.

A more comprehensive and critical understanding of the nature of this line of argumentation can be found in Chang:

The point here is that, using a purely neoclassical logic, one can justify an enormous range of state intervention ... Thus seen, whether a neoclassical economist is an interventionist or not depends more on his/her political preference rather than the 'hard' economics that he/she practices. (Chang, 2000, p. 7)

Next, we present different lines of argumentation concerning the appropriateness of public financial institutions within the market, given the existence of market failures. An emphasis on certain consequences of their poor performance distinguishes these arguments from those already discussed. However, all arguments are ultimately rooted in the concepts of market failures and the generation of externalities since they are predicated on the perception that it is the role of public banks to allocate credit to sectors and segments that the market otherwise fails to provide for adequately. In this sense, they form what we have called the conventional view, which we consider extremely narrow.

The social view emphasizes that the public sector's role, and more specifically the role of public banks, is to compensate for market imperfections that leave 'socially profitable' investments without financing (Yeyati et al., 2007). Therefore, the emphasis is on a deficiency generated by markets that do not finance socially important investments.

In turn, the view that financial institutions are not capable of performing as development agents in the market is the critique that underlies the development view (Stiglitz and Uy, 1996). This line of argumentation stresses the need for intervention in specific situations stemming from the poor functioning of existing markets or even from the non-existence of such markets, and thus represent an obstacle to development. Among these situations it is worth highlighting capital scarcity, general public distrust, and endemic fraudulent practices among debtors (Yeyati et al., 2007). The state's direct intervention via the ownership of financial institutions enables it to raise resources and allocate them to projects of interest, such as long-term strategic projects, which may mitigate failures that hinder the functioning of the private stock market. Therefore, projects that are interesting from a social point of view, but not appealing to private capital, or that are too large for the amount of private capital available, could still be financed, contributing to further development (Stiglitz and Uy, 1996). It must be emphasized that this line of argumentation is essen- 
tial to the social view, which manages to bring these two positions closer together. The argument in favour of the presence of public financial institutions contends that they facilitate financial and economic development, since they allow for increased accumulation and productivity. A conclusion derived from this line of argumentation is that public banks are more appropriate in less developed economies, marked by the presence of less or little organized financial institutions and markets.

Also focusing on the problem of market failures and the generation of externalities in the banking sector, but noting a slightly different consequence, Rocha (2003) presents another 'line of defence' for state-owned financial institutions. Her central argument is that the state's absence in the provision of banking services, besides implying little commitment to universalizing these services, would limit investments in important segments of the production chain, such as infrastructure, research and development. The latter, fundamental to increasing productivity, are riskier, since their chances of failing are higher, perhaps indicating insufficient or even nonexistent resources for segments that provide higher productivity gains. ${ }^{1}$

This situation could be alleviated by the presence of public financial institutions, which can allocate credit to segments that provide productivity gains, since such institutions would: (1) be more willing to promote the internalization of positive effects and externalities; (2) not be subject to the same risks, given that state ownership and, consequently, state guarantee signify the impossibility of insolvency; ${ }^{2}(3)$ regard the social value of credit for essential sectors more than the risk of operations. According to Rocha (2003), another positive externality generated by the presence of public institutions is the enhancement of trust in the system. ${ }^{3}$ Thus, the generation of positive externalities could be divided into two orders of arguments. The first, also present in the so-called 'development view', is that, given its characteristics, credit provided by public banks would exert positive impacts on growth. The second is that the presence of these institutions would improve the reliability of the banking system. It is worth stressing that, according to Rocha (2003), public banks should seek to maximize social welfare, rather than focusing on profit maximization.

Contrary to the argumentation explained above, the 'political view' is quite critical of the existence of state-owned financial institutions, based primarily on the issue of their objectives and efficiency. On the one hand,

\footnotetext{
1 Rocha considers uncertainty as a result of the association of macroeconomic conditions, debtor's credit worthiness, adverse selection and moral risk.

2 The idea that permeates this line of argumentation is that the state would not allow one of its institutions to go bankrupt.

3 It is not possible to disregard the potential that this presence could generate moral risk and adverse selection.
} 
politicians' intent to pursue their personal objectives permeates state ownership of financial institutions, potentially conflicting with resource allocation to socially efficient uses. Controlling public banks politically, politicians would be able to create employment, as well as generate subsidies and other benefits as means to obtain electoral, but not 'economic' or 'social' advantages (LaPorta et al., 2002). On the other hand, such institutions would finance politically interesting, but otherwise inefficient projects. Projects not financed by the private sector may still be socially uninteresting, and additionally could decrease productivity, contrary to what the externalities/development position advocates (ibid.). Besides, public institutions could crowd out private companies by taking on their roles and resources. Therefore, the conclusion is that government failures prove to be a greater risk than market failures. According to this diagnosis, and considering scenarios in which public financial institutions are already present, the best prescription is privatization.

Another line of argumentation is deduced from the so-called 'agency view', which, according to some authors, can be understood as 'intermediary'. On one side, there is the social and development view, pointing to the benefits of direct intervention, and, on the other, there is the political view, indicating the deficiencies derived from intervention. In the middle of this spectrum stands the agency view (Novaes, 2007; Yeyati et al., 2007). The 'intermediary' nature of this view results from synthesizing this polarity through the idea that the service (credit allocation) could be rendered, in principle, either by a public agent or by a private agent hired by the state. The answer would depend on the nature of the contract made between them.

As for banks, the problem, which would point to the inappropriateness of the state's direct presence, stems from a lack of quality in the interaction between agents - public institution administrators - and the principal governors and policymakers, who stand as democratic representation (Pinheiro, 2007). A poor relationship between agent and principal may result 'in weak administrative incentives that may cause corruption, technical inefficiency and poor allocation of resources' (Pinheiro, 2007, p. 162).

From the debate presented above, we deduce that, in essence, all discussion surrounding state intervention, particularly as the owner of financial institutions, is built on the concepts of market failures (or imperfections) and the generation of externalities.

\section{Public Banks: The Non-conventional Controversy}

Another order of arguments - called here the 'non-conventional' - found in the literature, and that in some way serves as a foundation for government intervention in credit markets, is based on the belief in the importance 
of financing mechanisms that guarantee crucial decisions, especially on investment, and that are not frequently provided by private agents. It is worth emphasizing that some of the arguments brought forward by the authors discussed here refer to government intervention, which does not necessarily mean intervention through public banks. However, we believe that these arguments contribute convincingly to a reflection on the role these institutions play. Moreover, it is important to stress that the arguments are based on specific institutional contexts, which might explain the proposed forms of intervention, but certainly does not preclude a broader reading of the intervention process itself.

Minsky et al. (1996) write from the perspective that the key role of a financial structure is to guarantee the accumulation of capital in order to promote production capacity growth and wealth generation within an economy. In this sense, they defend that whenever banking activities are not adequately performed by those institutions already active in the market, there is room for government intervention, mainly via credit supply and though saving and payment mechanisms for given segments of the population such as low-income individuals, ethnic minorities and small business in particular.

Thus, one can observe that the defence of intervention is predicated upon the existence of gaps in service supply for given segments and regions, especially within the credit market. This position highlights the importance of financial services, particularly financing mechanisms to guarantee decisions on expenditures, income generation and, consequently, economic development:

Capital development of the country, in general, and of depressed regions, in particular, requires a broad range of financial services in order to raise effective demand and revitalize the regional and national economies. In other words, 'capital development' is the primary concern ... this includes the provision of financial services to all segments of the economy, including consumers, small and large business, retailers, developers, and all levels of government. (Minsky et al., 1996, p. 387)

The form of intervention considered in the above passage is the creation of Community Development Banks within the US financial system. This form (and not another) was probably proposed due to the institutionality and structure of that particular system.

Torres Filho (2007) develops a line of argumentation justifying the presence of public development banks based on a broader debate surrounding state intervention in credit markets. ${ }^{4}$ He builds on the

\footnotetext{
4 Certainly, when compared to the analysis by Minsky et al. (1996), the structural and
} 
observation that intervention occurs worldwide, albeit with different purposes, and acts in three areas: monetary policy, credit regulation and credit allocation (or earmarking). ${ }^{5}$

Intervention in the credit market in the form of regulation takes place as the enforcement of norms, mechanisms and public institutions to preserve the proper functioning of the financial market. As for monetary policy, determining shorter-term interest rates, it directly or indirectly influences credit demand and supply.

The direct intervention in credit allocation, differing from the other forms, does not focus on the market as a whole. Rather, it aims to generate or reallocate resources to sectors, regions or specific types of borrowers, such as micro, small and medium-sized companies. However, aware of the fact that this debate has an important and irremovable institutional dimension, Torres Filho demonstrates that the degree of intervention and its instruments vary considerably among countries.

One possible form for intervention, typical of the United States, is the provision of instruments that guarantee credit of private origin. However, this allocation may well assume another form, that is, through public banks, as seen in Brazil.

The aim of this section was to present and analyse a list of the most commonly debated arguments regarding public banks. As we have already pointed out, the discussion of public banks, regardless of the side one takes in respect to the need for their presence, focuses on their role either as institutions capable of minimizing market failures or, according to the non-conventional view, as institutions that can fill market gaps, given the crucial role of financing for certain spending decisions.

The authors ascribing to the non-conventional view have raised a fundamental issue, emphasizing the distinct hierarchy of certain categories of expenditures and the corresponding need to reduce the uncertainty that surrounds them, and hence deducing the need for the presence of the state. However, we intend to go further into this debate and present another set of ideas, complementary to this one, which helps to develop a more comprehensive - and appropriate - argumentation about the need for public banks.

institutional context of the present analysis is quite distinct, since Torres Filho's final objective here is to reflect on the Brazilian case.

5 Within the scope of this chapter, our focus is on credit allocation. 


\section{FINANCIAL STABILITY AND PUBLIC BANKS}

The role of public banks can, and must, go beyond that of facing deficiencies in the process of credit allocation. Considering Minsky's theoretical contribution as central, the purpose of this section is to discuss the role that can be played by public banks in the context of an economy marked by financial instability and the generation of inequalities.

Minsky is among the most important authors of the post-Keynesian theoretical approach. During the moment of the eruption of the international financial crisis, Minsky's work was transformed into a reference not only within the academic mainstream, but also often in major newspapers.

It is remarkable that an author as important as Minsky has broken through theoretical and ideological barriers and begun to emerge in almost trivial debates. Nonetheless, this phenomenon did not happen without sacrificing much of the theoretical richness found in his ideas. We must underline that in contrast to the media debate, the central question in Minsky is not characterizing a moment - the alleged 'Minsky moment', marking the start of a more open crisis process in financial markets with dire consequences for the 'real side' of the economy. Rather, the crucial contribution of his scholarship lies in his illumination of the precise nature and dynamics of a capitalist economy. At last, Minsky is not the theoretician of a moment, but of a movement, the movement of the capitalist economy with developed financial markets, which, as opposed to the postulate of the neoclassical thought, does not tend towards equilibrium. In Minsky's words:

In a world with capitalist finance it is simply not true that the pursuit by each unit of its own self-interest will lead an economy to equilibrium. The selfinterest of bankers, levered investors, and investment producers can lead the economy to inflationary expansions and unemployment-creating contractions. Supply and demand analysis - in which market processes lead to equilibrium does not explain the behavior of a capitalist economy, for capitalist financial processes mean that the economy has endogenous destabilizing forces. Financial fragility, which is a prerequisite for financial instability, is, fundamentally, a result of internal market processes. (Minsky, 1986 [2008], p. 280)

It is important to stress the meaning of this passage, which is far from trivial. The author points to the fact that, in a developed capitalist economy - that is, one with developed financial systems - the expected result from the agents' endless search for their own interests is not equilibrium. It is quite the opposite - disequilibrium and instability. In addition, Minsky shows that the heart of this instability may be found in the unbalanced behaviour of financial markets, and that such disequilibrium does 
not result from a 'failure' introduced 'from the outside'. On the contrary, disequilibrium is endogenous; it is in the nature of the system itself. To Minsky, instability is the counterpart of a system that seeks continuous expansion. Finally, it should be clearly stated that, to Minsky, a capitalist economy with developed financial systems does not tend to an optimizing equilibrium.

From this point on, the issue to be discussed is how such instability is, or should be, faced. In other words, how is it best mitigated on the one hand and what leads to its intensification on the other? The author's answer is that institutions, created within societies during certain economic and political conjunctures, play this crucial role.

Minsky's analysis of the behaviour of capitalist economies, emphasizing their inherent tendency to generate fragility and instability, allows for a different perspective on the discussion about public banks, opening space to reflect on their performance in much more general - and appropriate terms than those based on failures, or even on market gaps, especially in the process of credit allocation. We contend that the importance of and the need for such institutions as public banks are better evaluated from this point of view. For public banks can, and must, be considered in the context of institutions capable of contributing to higher efficiency in the service provided to given segments of the financial (or credit) markets, and also able to assure more stability in the financial system and the economy as a whole:

Decentralized markets are fine social devices for taking care of the particular outputs and prices of an economy, but they are imperfect devices for assuring stability and guaranteeing efficiency where large expensive capital assets are used in production. But most important, capitalist market processes that determine the prices of capital assets and the flow of investment introduce strong destabilizing forces into the system. Once we achieve an institutional structure in which upward explosion from full employment are constrained even as profits are stabilized, then the details of the economy can be left to market processes. (Minsky, 1986 [2008], p. 329)

Minsky's perspective is radically opposed to that of the mainstream, asserting the destabilizing role of markets and the (potentially) stabilizing role of institutions created not by markets, but by governments. Therefore, the presence of institutions with a logic of action that differs from that of the market is necessary in order to counteract destabilization. Besides pointing to the need for intervention in key markets, he holds the view - logically derived from his analysis of the economy's unstable dynamics - that deep and long-lasting recessions are not observed today as a consequence of the important role played by governments: 
Big Government is the most important reason why today's capitalism is better than the capitalism which gave us the Great Depression. With Big Government, a move toward a deep depression is accompanied by a large government deficit that sustains or increases business profits. With profits sustained, output and employment are sustained or increased. (Minsky, 1986 [2008], p. 330)

The central stabilizing role of the state in modern capitalist economies in many economies, takes the form of active public banks, which in some cases could be called 'big government banks', as they are integral parts of the government structure.

Andrade and Deos (2009) make an effort to conceptualize public banks from a Keynesian-Minskyan theoretical perspective not limited to the conventional idea of public banks as institutions that act to correct market failures. The authors also criticize the use of this concept within the discussion surrounding the need for and appropriateness of public banks. They argue that, more than correcting failures, such institutions structure markets in which the private sector is reluctant to act.

For Andrade and Deos, a public bank is characterized as an institution that performs activities that exceed the traditional, but important, role of providing long-term development and credit lines to segments politically defined as priorities and that the market does not serve properly. Public banks go, or should go, beyond this point when (1) defining new financial products and/or new conditions for existing products, so as to induce the market to operate on new foundations, engaging in financing politics in a broad sense; (2) operating in the market to change its 'natural dynamics', clearly procyclical, as a privileged means to convey the impacts of decisions made within the scope of monetary and credit policies; (3) taking action in the credit market to minimize uncertainty, especially in moments when it is exacerbated, since in such circumstances there is a natural and defensive 'shrinking' of private credit. The latter occasion for public bank action is very close to conclusions drawn from the Minskyan discussion. The authors observe that, when playing its role as a public bank, an institution should not be primarily concerned with profitability. They demonstrate that, if profitability is the institution's main concern, this may indicate that its public role is not being adequately fulfilled.

In Mollo (2005), we also find a broader analytical perspective on the role of public banks, following in Keynes's and Minsky's footsteps. Mollo discusses unstable monetary and financial dynamics that enlighten the reflection on the need for public banks and on their role in general. For her, parallel to the development of financial markets and increasingly liquid instruments, there is an increase in the speculative dimension of the system and in its instability. In this sense, she points to the need for state regulation, which we can understand in a broad sense, either involving indirect 
intervention, such as prudential regulation, or direct intervention, including the use of public banks.

Besides highlighting the endogenous aspect of financial instability, Mollo stresses another interrelated dimension, concerning the increase in social, sector, and/or spatial (regional and even national) inequalities as consequences of the market logic. The need for regulation/intervention to reduce inequalities does not derive from an 'absence' of the market. On the contrary, it is the outcome of its full functioning, and the state's role is to break with its logic. Thus, it is necessary to design discretionary policies, redefining actions in the monetary and financial domain, both to guarantee investment financing, promoting employment and income growth, and to counteract instability and inequalities.

The message conveyed by the authors analysed in this section is that the role of public banks can, and must, go beyond the role traditionally discussed, that of acting to resolve deficiencies in the credit allocation process, stressed by what we have called the 'conventional view' and 'nonconventional view'. Here, we advocate that these institutions can, and must, be used to face issues such as the instability and inequalities generated by the normal functioning of the market.

\section{CONCLUSION}

Following the intense crisis experienced in central and peripheral financial markets at the end of the first decade of the 2000s, a shift occurred in the debate on the role of public banks away from the previous two decades of extremely negative assessments, especially within some multilateral institutions.

Written in this context, our purpose here was to reflect on the various perspectives and concepts that permeate the debate on the role of public financial institutions. It is worth observing that the boundaries for a reflection on the 'general' role of these institutions are circumscribed by an analytical exclusion of the historical moment, the institutional framework, and the economic and financial structure in which they perform. We should stress that ignoring these specificities impoverishes the exercise of theoretical reflection, and even detaches it from context-specific realities.

The literature review indicates that most authors who discuss public banks understand that the role to be played by these institutions is coupled with a perception of some immaturity, or incompleteness, in the development of banking systems and markets. In this sense, public financial institutions are justified as a way of correcting the failures or filling the gaps left by the private sector as it fails to meet the credit demands of given 
economic segments and geographical areas, and to provide certain types of financial services. We have noticed that such a position is held by authors whose work is based on a conventional (neoclassical) theoretical approach and those who adopt a heterodox approach, all firmly tied to the perspective of effective demand.

The discussion about resource allocation in credit markets is truly fundamental, especially considering the importance of financing spending decisions that generate income and employment, further emphasizing the existence of a hierarchy among spending categories as well as a need for reducing the uncertainty that surrounds them. These critical issues all point towards the need for an active state presence within markets. However, we have sought to go beyond this dimension and present another set of ideas, complementary to this one, which help to build a more comprehensive - and, in our opinion, more appropriate - argumentation about the need for public banks.

For such purpose, we started from a Keynesian-Minskyan theoretical approach and concluded that public banks can, and must, be used to reduce the inherently cyclical behaviour of markets, acting to slow both their contraction and expansion by applying an alternative logic. At the same time, public banks should be used to reduce sector or regional inequalities generated and reinforced by the market. Finally, the key role played by government banks, perhaps deemed 'Big Government Banks', to face severe situations of instability and the generation of inequalities that result from the normal functioning of the markets should now be beyond question.

\section{BIBLIOGRAPHY}

Andrade, R. and S. Deos (2009), 'Trajetória do Banco do Brasil no período recente (2001-2006): Banco Público ou Banco Estatal', Revista de Economia Contemporânea, 13(1), 47-79.

Burgess, R. and R. Pande (2005), 'Do rural banks matter? Evidence from the Indian social banking experiment', American Economic Review, 95(3), 780-95.

Caprio, G., J. Fiechter, M. Pomerleano and R.E. Litan (eds) (2004), 'Introduction', in The Future of State-Owned Financial Institutions, Washington, DC: Brookings Institution Press.

Chang, H.-J. (2000), 'An institutionalist perspective on the role of the state: Towards an institutionalist perspective', in L. Bulamarqui, A. Castro and H. Chang (eds), Institutions and the Role of the State, Cheltenham, UK and Northampton, MA, USA: Edward Elgar Publishing, pp. 3-26.

Hanson, J. (2004), 'The transformation of state-owned banks', in G. Caprio, J. Fiechter, M. Pomerleano and R.E. Litan (eds), (2004), The Future of State-Owned Financial Institutions, Washington, DC: Brookings Institution Press, pp. 13-49. 
Jeanneau, S. (2007), 'Evolving banking systems in Latin America and the Caribbean: Challenges and implications for monetary policy and financial stability', BIS Papers No. 33, Basel: Bank for International Settlements.

La Porta, R., F. Lopes-de-Silanes and A. Shleifer (2002), 'Government ownership of banks', The Journal of Finance, 57(1), 265-301.

Lapavitsas, C. (2009), 'Systemic failure of private banking: A case for public banks', Research on Money and Finance Discussion Paper No. 13, London: Department of Economics, School of Oriental and African Studies.

Marston, D. and A. Narain (2005), 'Observations from an International Monetary Fund survey', in G. Caprio, J. Fiechter, M. Pomerleano and R.E. Litan (eds), The Future of State-Owned Financial Institutions, Washington, DC: Brookings Institution Press.

Micco, A. and U. Panizza (2006), 'Bank ownership and lending behavior', Economics Letters, 93(2), 248-54.

Minsky, H. (1986 [2008]), Stabilizing an Unstable Economy, New York: McGraw Hill.

Minsky, H., D. Papadimitriou, R. Phillips and R. Wray (1996), 'Community Development Banks', in D. Papadimitriou (ed.), Stability in the Financial System, London: Macmillan, pp. 385-99.

Mollo, M. de Lourdes (2005), 'Por uma dinâmica monetária e financeira menos excludente' [For a less excluding monetary and financial dynamics], in J. Sicsú, L.F. Paula and M. Renaut, Novo Desenvolvimentismo: Um Projeto Nacional de Crescimento com Equidade Social, Barueri: Manole/Konrad Adenauer.

Novaes, A. (2007), 'Intermediação financeira, bancos estatais e o mercado de capitais: A experiência internacional' [Financial intermediation, state banks and the capital market: International experience], in A. Pinheiro and L. Oliveira Filho (eds), Mercado de Capitais e Bancos Públicos: Análise e Experiências Comparadas, Rio de Janeiro/São Paulo: Contra Capa Livraria/ANBID.

Pinheiro, A.C. (2007), 'Bancos públicos no Brasil: Para onde ir' [Public banks in Brazil: Where to go], in A. Pinheiro and L. Oliveira Filho (eds), Mercado de Capitais e Bancos Públicos: Análise e Experiências Comparadas, Rio de Janeiro/ São Paulo: Contra Capa Livraria/ANBID.

Rocha, M. (2003), Privatização no Sistema Bancário e o Caso do Banespa [Privatization in the Banking System and the Banespa Case], Belo Horizonte: FACE/FUMEC.

Stiglitz, J.E. (1994), 'The role of the state in financial markets', in Proceedings of the World Bank Annual Conference on Development Economics, Washington, DC: The World Bank.

Stiglitz, J.E. and M. Uy (1996), 'Financial markets, public policy, and the East Asian miracle', World Bank Research Observer, 11(2), 249-76.

Torres Filho, E. (2007), 'Direcionamento de crédito: O papel dos bancos de desenvolvimento e a experiência recente do BNDES' [Direction of credit: The role of development banks and the recent experience of BNDES], in A. Pinheiro and L. Oliveira Filho (eds), Mercado de Capitais e Bancos Públicos: Análise e Experiências Comparadas, Rio de Janeiro/São Paulo: Contra Capa Livraria/ ANBID.

Yeyati, E., A. Micco and U. Panizza (2007), 'A reappraisal of state-owned banks', Economía, 7(2), 209-47. 